\title{
Implementation Legislative Election Campaign Taufiqulhadi
}

\author{
Rika Permata Sri ${ }^{1}$, Poppy Ruliana ${ }^{2}$, Irwansyah ${ }^{3}$ \\ ${ }^{1}$ Magister Student in Communication Studies, InterStudi College of Communication Sciences \\ ${ }^{2}$ Masters in Communication Sciences - InterStudi College of Communication Studies \\ ${ }^{3}$ Communication Studies. FISIP. University of Indonesia, Depok, 166424 \\ Corespondence Author's Email: rikapermata83@gmail.com
}

\begin{abstract}
Thank you for the second time running for the legislative candidate for the Republic of Indonesia 2019-2023 period with a different electoral area, namely the Bogor Regency, because it is necessary to improve the political communication strategy. The purpose of this study is to explain the political communication strategy of political communication in the implementation of the Taufiqulhadi campaign. The concepts used in this study are political parties, strategies, political communication strategies and campaigns and legislatures. The key informant in this study was T. Taufiqulhadi, while the informant was the head of the T. Taufiqulhadi volunteer team as the informant, who was involved 2 people who were directly involved in planning the communication strategy in the legislative campaign campaign. Data collection is done through gathering participation, in-depth interviews, literature and organizing data from web pages to facilitate researchers in the process of obtaining information and data. Data analysis techniques are carried out through the stages of data reduction, data presentation, and conclusion completion or verification. The results showed the communication strategy in the implementation of the $\mathrm{T}$ Taufiqulahadi legislative election campaign to win the legislative elections for members of the Republic of Indonesia House of Representatives was effective. but the party votes that support the small Democratic National political party then $T$ Taufiqulhadi was not elected as a member of the Republic of Indonesia DPR 2019-2023 period, The findings in this study are the style of communication
\end{abstract}

Keywords: strategy, political communication, communication strategy, campaign, legislative

\section{INTRODUCTION}

As a result of the elections that have taken place in Indonesia, the success of a candidate who is eligible to become a member of the board is determined based on the party's serial number. In contrast to the current legislative elections (2014), those who are promoted to become candidates must work hard to get votes, because the determination of candidates is determined by the most voting system. This is related to the decision of the Constitutional Court which partially granted the petitioners' petition regarding the case review. Law Number 8 of 2012 concerning General Elections of Members of the People's Legislative Assembly, Regional Representatives Council, and Article 5 of the Region, DPD, and DPRD are 
implemented with an open proportional system, while Article 215 concerning the determination of legislative candidates is based on legislative candidates who get votes the most.

Based on the decision of the Constitutional Court regarding the most votes above, the candidates were asked to make maximum efforts to get as many votes as possible from the public. Therefore, this decision made fierce competition, both legislative candidates between political parties and within the political parties themselves. In this position, each candidate releases their abilities, strategies and resources to compete for the most votes in their constituencies. Political communication and campaign strategies of legislative candidates are very important positions so that they can win the hearts of the people

The position of legislative members is a mandate given by the public to channel their aspirations in parliament. To become a member of the board there is no limit on how many times to run for office, while still being able and getting support from the community means that they are still entitled to become a member of the board, therefore, Teuku Taufiqulhadi, running for the legislative candidate from the National Democratic Party with the electoral district V Bogor Regency where previously Taufiqulhadi was elected as a member of the DPR of the Republic of Indonesia in the 2014 Election from the NasDem party with electoral districts in East Java IV including Jember Regency and Lumajang Regency by winning as many as 22,075 votes. Taufik ran again as a member of the council and was supported by the Democratic National Party

As a member of NasDem it launched its own communication strategy in conducting campaigns to win candidates for the House of Representatives. The Secretary General of the NasDem Party, Jhonny G Plate (on the web page, Kontan.co.id, 116, July 2018) said, the strategies used by the NasDem party in conducting campaigns were political competence, candidate competition, candidate integrity, and electability. from the candidate. The NasDem party is preparing based on the change gate tageline. To win the competition in the arena of legislative elections, implement various effective political communication strategies. Of course, political communication carried out by political parties adapts to the existing political system in Indonesia. Therefore, the political system inevitably also influences and is influenced by communications made by political parties.

Political communication strategies in carrying out campaigns carried out by political party legislative candidates to the public are needed in the face of elections. The success of political communication strategies by political parties in planning and implementation, will play a role in the results of the ballot later. This political communication strategy, by many candidates and political parties often utilizes interpersonal communication skills and mass media, both electronic and print media. Intensive communication carried out by a candidate indicates an attempt to embed certain "images" and "brands" in the public mind. For example, when a legislative candidate raises a "health" problem, at least this is an attempt by a Political Party / Candidate to build the image that health problems are important things that they always pay attention to. Another example, the slogan "eradicate corruption", is also an effort of political parties / candidates to make the slogan as 
an "image" in their political parties. If this effort is firmly planted in the minds of the people, then the enthusiasm of the community will be strong towards the political parties or candidates who carry the problem. This fact will make it difficult for political parties or other candidates, if they want to shake the position in the minds of the people. The communication strategy not only concerns the contents of the message sent to the intended audience, but also the communication channels used and what effects are expected in the implementation of the campaign.

Based on these problems, it is necessary to study how the Political Communication Strategy in the implementation of the Legislative Candidate Campaign. Taufiqulhadi in Bogor Regency

\section{LITERATURE REVIEW OR RESEARCH BACKGROUND Strategy}

In research related to political communication strategies in campaign implementation, the concept of strategy itself is very important and even prioritized in studying political communication strategies, Henry Mintzberg (in Amon Yadi, 2014) said that many people use the word strategy in several ways, according to him there are four what is commonly used as the following statement: 1. Strategy is a plan "how" something is achieved from "here" to "there" 2. Strategy is an example of an activity such as a company that routinely markets products widely using the "high strategy" button -end "button. 3. Strategy is a position such as a reflection of decisions in offering certain products and services in certain markets 4. Strategy is perspective, namely vision and goals.

\section{Political Communication}

The study and practice of communication focuses on ways and means of expression that are political in nature. Robert E. Denton and Gary C. Woodward (1998), two contributors important in this field, in Political Communication in America describe it as a means and purpose of sending messages to influence the political environment. This includes public discussions (eg political speeches, news media coverage, and ordinary citizen talks) that consider who has the authority to impose sanctions, the allocation of public resources, who has the authority to make decisions, as well as what social meaning makes a people become Americans. In their words, "the important factor that makes communication 'political' is not the source of the message, but the content and purpose." David L. Swanson and Dan Nimmo (1999), also define political communication as "the strategic use of communication to influence public knowledge, trust and action on political matters." They emphasize the nature of political communication strategies, highlighting the role of persuasion in political discourse.

Brian McNair gave the same definition when he wrote that political communication is "communication aimed at politics." For McNair (2003) this means that this includes not only verbal or written statements, but also visual representations such as clothing, make-up, hairstyle, or logo design. In other words, it also covers all aspects that develop "political identity" or "image". Thus, the core of political communication is communication that is directed to achieve influence 
in such a way that the problems discussed by this type of communication activity can bind a certain group or citizen. Thus political communication is the effort of a group of people who have a certain orientation, political thought or ideology to control or gain power. (Rauf, 1993).

Political communication is a field of communication related to politics. Communication often influences political decisions and vice versa. The field of political communication involves 2 main areas: 1. Election campaigns - Political communication is related to campaigns for elections. 2 Political communication is one of the Government's operations. This role is usually fulfilled by the Ministry of Communication and or Information Technology

\section{Political Communication Strategy}

Vian Bakir (in Susanto, 2013) defines a political communication strategy as consisting of 'political communication that has manipulative objectives, which use social scientific techniques and heuristic tools to understand human motivation, human behavior and the media environment, to effectively inform what needs to be communicated - including details and overall direction - and what must be withheld, with the aim of calculating and influencing public opinion, and creating strategic and enabling alliances for government policy both at home and abroad. Whereas Stromback \& Kiousis, (2014) states that political communication strategies can be used to achieve objectives in the selection and policy making. It can also be used for purposes such as increasing internal cohesion or forming media coverage. It was stated that the strategic objectives parties and campaigns are very important, which shows that understanding political communication strategies during election campaigns requires understanding political parties and campaigns as organizations

The purpose of a political communication strategy during an election campaign is to use information and communication as strategically and effectively as possible to achieve the stated goals. Thus, the strategic objectives of parties and campaigns are very important, which shows that understanding political communication strategies during election campaigns requires understanding political parties and campaigns as organizations (Stromback \& Kiousis, 2014)

To develop a communication strategy proposed by Arifin (Effendi: 2000) with the aim of producing effective communication, there are several things that must be done as follows (1) know the audience, (2) compile the message (3) determine the techniques for conveying the message and (4) choose the media.

\section{Get to Know the Audience}

The public in the general election is known as voters, voters in this case can be in the form of constituents and the general public. Understanding the factors underlying voters in voicing their opinions is something that is important, both in theory and practice (Quist \& Crano, in Tosepu 2017) in Firmanzah (2012). According to Downs (in Wilhelm Hofmeister and Karsten Grabow, 2011) Voter interest in contestants can be explained by using the proximity model or the 'spatial' model (Downs, 1957) in this model voters will tend to choose political parties or contestants who are considered to have similarities and closeness of values . and 
belief systems. Two things can be used as a measure of its proximity to political parties or contestants, that is; equality about how to solve problems (problem solving policies), and similarities in understanding and ideological basic values (ideology) with one political party or contestant.

Election contestants must be able to identify groups in society to more easily understand the characteristics of each group of people, this activity is known as segmentation. Each community group needs a different approach and method of communication, just as rural communities need a different approach to methods of communication with urban communities due to different background conditions. Segmentation is needed to regulate party work programs, especially how to communicate and build interaction with the community. Without segmentation, contestants will have difficulty in compiling political messages, work programs, political campaigns, political socialization, and political products. Carrying out segmentation means that political parties or contestants use an information-based political approach, that is, political parties seek, absorb, and process information about conditions in society. (Firmanzah: 2012). Through segmentation contestants can compile voter profile that will become a political target later, this activity is called political targeting. Develop political targets based on measurement standards for the number and size of potential voters. Groups of people who have large populations are favorable political targets to approach, because they are a large number of votes. Another measurement standard is the importance and influence of groups in influencing public opinion, even though community groups do not have a significant influence in influencing public opinion so it is appropriate to be approached by election contestants. After targeting, the next step is to determine the position, namely placing the political message and political product into the segment chosen correctly and appropriately to create contestant's identity in the eyes of the voters. (Firmanzah: 2012).

\section{Compilation of Messages}

Determination of the contents of the message intended packaging the themes and materials needed in influencing the audience to send the message, so that it can arouse attention. According to Wilbur Schramm, quoted by Effendi (2004), the message to be delivered by a communicator must meet the following requirements: a. A message must be planned and delivered in such a way that the message has value in attracting the attention of the intended audience.b. Messages must use symbols based on the same experience between source and target, so that they have the same understanding. c.he message must generate personal advice about a need (in this case the need for stable political conditions) so that it can suggest ways to achieve that need. d.The message should suggest ways to get needs that are appropriate for group situations where there is awareness when transferred to provide the desired answers.

The message of politics in general elections is political products marketed to consumers, in this case voters. Political products in the form of intangible products or intangible products that are closely related to the value system, are attached to promises and hopes for the future. Niffenegger (1989) 
divides political products into three categories, (1) party platforms, (2) past records (records of things done in the past), and (3) personal characteristics. The main product of political institutions is a platform, which contains the concepts, ideas, ideological identity of parties, and party work programs. What has been done by political parties or candidates in the past has contributed to the formation of political products. The characteristics of a leader or candidate provide a symbolic image, and the credibility of a product. (Firmanzah 2012)

The use of media is more a consideration of the most effective channels to be used in transferring messages to the public. In communication science is known as direct media (face to face) and mass media. The use of media is related to the promotion of political products. Media selection is an important factor in the penetration of political messages to the public. Knowing the different levels of media penetration (internet, TV, radio, print media such as newspapers and magazines in important fields is carried out to ensure the effectiveness of the political message to be conveyed. Promotion can be done through political debates on TV, mobilizing large numbers of people to attend "Tabligh- Akbar "or" Cadre Gathering. "Party symbols, symbols and colors distributed through pamphlets, banners and posters during the campaign period are also a medium to promote political institutions. These promotional activities are not only carried out ahead of the campaign, but must continue to be done so that the public always feel the presence of political institutions, always pay attention, accommodate and resolve public problems so that public trust grows in the process of interaction with political institutions. (Arifin: 2013)

\section{Campaign}

Uderstanding the campaign based on Law No. 1 of 2015 concerning General Elections for Members of the People's Legislative Assembly, Regional Representatives Council, and Regional People's Representative Council in article 1 number 26 is "the activities of the Election Contestants to convince voters by offering the vision, mission and program of the Election Contestants" Kotler and Roberto (in Cangara, 2016,) defines the campaign as "an important element contained in this understanding including groups called agents of change, then targets which are audiences or constituents, which are expected to accept, modify certain ideas, attitudes and behaviors". While Rogers and Storey (in Fatimah, 2018), a campaign is a number of planned communication actions aimed at creating a certain effect or effect on the public in large numbers and carried out continuously at a certain time. the definition given by Rogers and Storey is the most popular and widely accepted and recognized by several communication experts

In that case, the General Election Commission (KPU) through decision letter no. 35 of 2004 regulates all forms or types of campaigns. According to regulations, there are at least 9 types / forms of campaigns, namely: (1) Public debate / open debate between candidates, (2) Other activities that do not violate laws and regulations, (3) Installation of props in public places, (4) Dissemination of campaign material to the public, (5) Dissemination through print and electronic 
media, (6) Broadcasts through radio and or television, (7) Limited Meetings, (8) General meetings, and (9) Faces to face and dialogue (Fatimah, 2018).

\section{METHODOLOGY}

The approach used in this research is a qualitative approach is a method to explore and understand the meaning of a number of individuals or groups of people who are considered to originate from social or humanitarian problems (Creswell, 2016). The research method used is a case study. Case studies according to Yin (2011) are empirical investigations that investigate phenomena in real-life contexts, when the boundary between phenomena and contexts does not appear explicitly or clearly and uses various sources or sources of evidence. Case study research can be divided into three types, each of which is an explanatory type, namely to explain the causal relationship in a real life context. Exploration type, which is used to explore situations that cannot be evaluated by intervention or based on a single point. And the next type is descriptive which is used to describe phenomena that occur in real life. In research using the type of case study. Descriptive. This is consistent with the opinion of Bungin (2011) argues that the qualitative descriptive format is generally carried out in research in the form of case studies and focus on certain units of various phenomena. The unit under study is the individual unit, Taufiqulhadi. Data collection was carried out through participant observation, indepth interviews, with key informants namely Taufiqulhadi and 2 informants as Chairperson of the Volunteer Team and documentation and internet to obtain information and data in accordance with the research objectives. Data analysis, there are three qualitative data analysis techniques, namely data reduction, data presentation and verification or conclusion drawing. (Miles and Huberman (in Sugiyono, 2009) Data testing is conducted to fulfill data credibility. Considering the validity in qualitative research needs more evidence so that the research results obtained do not need to be doubted (Sugiyono 2009)

\section{RESULTS AND DISCUSSION}

Based on information and data collected by researchers by interviews and document studies, various findings related to communication strategy research are divided into three parts. First is the superior strategy. The second strategy is to choose the audience, the second is the strategy to choose political messages, the third is the strategy to use the media, which refers to Arifin's opinion

\section{T. Taufiqulhadi's Legislative Election Campaign Strategy.}

From the results of the interview on May 20, 2019 at Bogor, conducted by researchers, information was obtained from key informants who stated that in the implementation of the campaign program assisted by Restu stands for Volunteer Taufqulhadi consisting of 5 administrators in the Regency, and for the District level as many as 40 people while 
for the Village level as many as 435 volunteers so all volunteers totaled 480 people. They have been working for one year with a focus on the sick who are unable and this blessing is an extension of the Saku Amanah Foundation which only exists in Bogor Regency. This foundation is an independent foundation that works in a social context, with an emphasis on community welfare

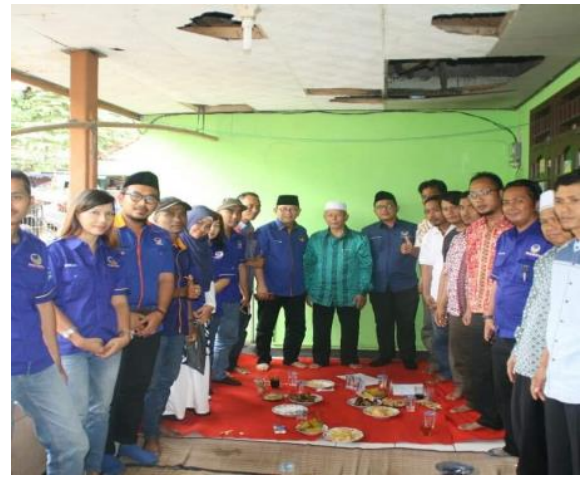

Photo 1: Group photo when taking part in the socialization in Sukahati Cibinong Village

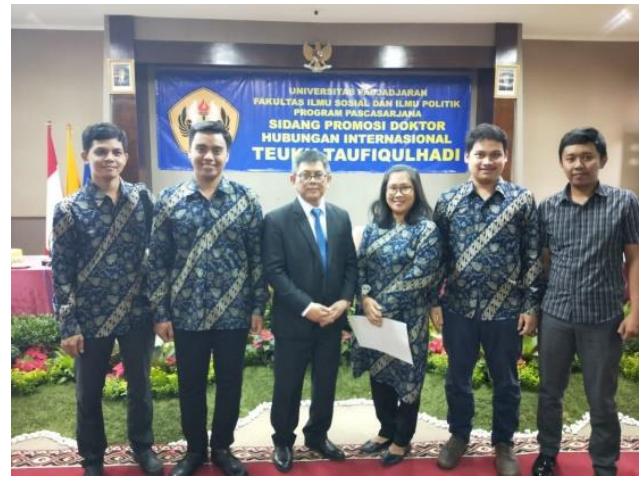

Photo 2: Photo with Restu's core team after the Interview

Then Team Leader Restu added that the strategy is socialized and is expected to be able to build the confidence of voters and make good use of promulgation programs and elect Taufiqulhadi as a member of the DPR RI 2019-2023 period

Based on these strategies, the communication strategy planning is designed which can be explained as follows:

\section{Audience Selection Strategy}

Before deciding on an election strategy to determine the audience's target, Restu's team conducted research in the Electoral District, namely Bogor Regency, which is the center of government in Cibinong District. Bogor Regency consists of 40 sub-districts and 435 villages which are divided into several villages and subdistricts. The central government of Bogor Regency is located in the District of Cibinong, which is in the north of Bogor City by using segmentation techniques based on geographical, demographic, psychographic, behavioral, social and cultural characteristics of the people living in Bogor Regency.

The segmentation technique used by the Restu Team is to group communities according to the social and cultural characteristics of the community and identify groups in the community to facilitate understanding of the characteristics of each group in the community. Communication approaches and methods applied are different, such as rural communities that require different communication approaches from urban communities due to educational and social background 
conditions. Segmentation is needed by organizing party work programs, especially how to communicate and build interaction with the community in Bogor Regency. The importance of segmentation was felt by the Restu Team because without segmentation, it would be difficult to prepare political messages, work programs, political campaigns, political socialization, and political products. By applying segmentation, it means that political parties or contestants use an information-based political approach, namely political parties seeking, absorbing and processing information about conditions in society (Firmanzah: 2012). Meanwhile, to determine the target audience segmentation, the Restu Team conducted preliminary research to find out what problems arose in the targeted community or targeted political campaigns based on the initial conditions of the community regarding traditional values or community culture, education levels in the community. or the level of voters, the economy of the community and getting to know the NasDem party by the public and the mass media about the Taufiqulhadi news related to the reputation as a member of the DPR, experts commenting on the figure of Taufiqulhadi as a political communicator.

Based on the description, the problem can be identified, this program can be made in accordance with the wishes and needs of the community in Bogor Regency. One of the problems that arose was a health problem, so the Restu Team compiled a Health Program which he considered a strategy considered to be very important and effective because it is in accordance with the wants and needs of the people in Bogor Regency. There are several superior strategies carried out in the implementation of the Legislative Election campaign according to the Head of the Restu Team as follows:

The strategy in implementing the Taufiqulhadi campaign is firstly, implementing a health program that helps people in the health sector by registering people who do not yet have a BPJS card and providing assistance until finally getting a BPJS card and helping people who experience health / illness. The second program is to provide ambulance assistance for people in need and the third program is an education program by providing assistance to pesantren that will collapse, and providing salaries to the Koran teachers considered to be very important and effective because it is in accordance with the wants and needs of the people in Bogor Regency. There are several superior strategies carried out in the implementation of the Legislative
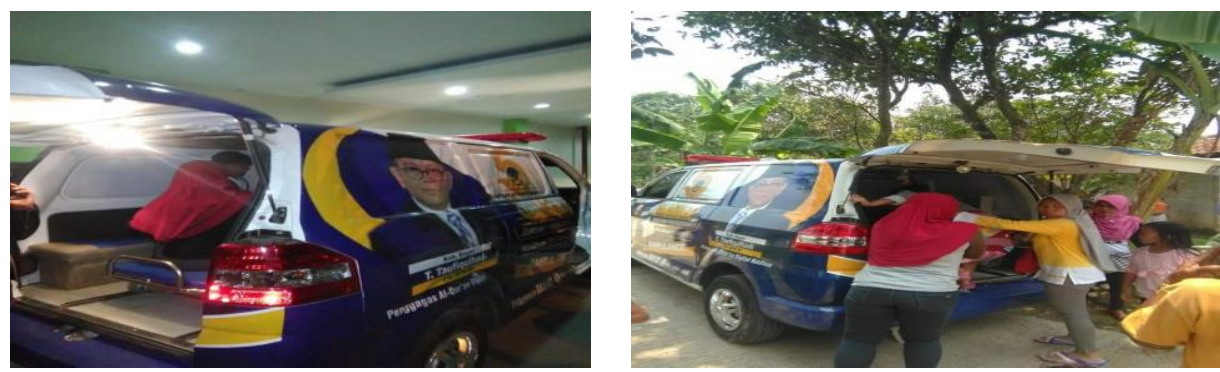

Photo 3: Ambulance Car Assistance 
With this strategy it is expected to become an attraction so that the community will support and elect $\mathrm{T}$ Taufiqukulhadi as the DPR legislative candidate for the 2019-2024 period because T Tauifiqulhadi is considered capable of solving problems that occur in society and understanding the similarities in the basic ideological values of the NasDem party and listening to the aspirations of the people This is in accordance with what was stated by Downs (in Tosepu, 2017) which states that there are two things that can be used as a measure of its proximity to political parties or contestants yaikni; equality about how to solve problems (problem solving policies), and similarities in understanding and ideological basic values (ideology) with one political party or contestant. In addition, each legislative candidate will be demanded to always be a forum for the aspirations of the people so that every elected candidate must be prepared to listen to the aspirations of the people.

\section{Message Selection Strategies and Political Message Techniques}

Research findings in the implementation of a political message selection strategy delivered by Taufiquhadi prioritize the public interest and its interests as candidates for legislative members. This was conveyed by the Head of the Restu Team who stated this

The political message conveyed by the Restu NasDem Team by paying attention to the educational, social and economic background of the Bogor community is related to the value system and tradition or culture, embedded in the spirit and hope that will be realized if elected as a legislative member. The message content is a political product delivered by Taufiqulhadi as a political communicator or legislative candidate for the DPR, first conveying the vision and mission of becoming a legislative member based on the NasDem party platform. Second, the notes that have been done by Taufiqulhadi in the past, and personal characteristics.

\section{NasDem Party Platform}

The message conveyed by Taufiqulhadi in the implementation of the DPR candidate campaign to the community in Bogor Regency was based on the vision and mission formulated by the NasDem Party. There is also a vision and mission are as follows:

\section{Vision and mission}

Building Democratic Democratic Politics means creating democratic reorganizations that open up people's political participation by opening access to society as a whole. Developing a model of civic education to strengthen the nation's character, as well as making changes towards the efficiency of the electoral system. Strengthening bureaucratic reform to create a community service system. Carry out legal reforms by making the 1945 Constitution (1945 Constitution one thousand nine forty-five) as a national political contract. 


\section{Vision}

Indonesia is independent as a nation state, economically sovereign, and dignified in culture

.Mission

1. Building Democracy Democratic means creating democratic reorganization that opens people's political participation by opening access to society as a whole. Developing a model of civic education to strengthen the nation's character, as well as making changes towards the efficiency of the electoral system. Strengthening bureaucratic reform to create a community service system. Carry out legal reforms by making the 1945 Constitution (Law

2. Creating Economic Democracy through an economic democratic order will create public participation and access in the economic life of the country, including fair and equitable economic distribution that will lead to the welfare of all the people of Indonesia. In realizing this goal, it is important to encourage job creation, national social security systems, strengthen national industries, and encourage economic independence at the local level.

3. Making mutual cooperation culture as a national character. In realizing this, a system that guarantees the implementation of a structured national education system and guarantees the right to education for all Indonesians. Conducting civic education that creates national solidarity and solidarity, so that all Indonesians feel the meaning of being a nation and make mutually beneficial cooperation a daily life practice. This culture will create a dignified national character and maintain the readiness of the State in global life Message Selection Strategies and Political Message Techniques

Research findings in the implementation of a political message selection strategy delivered by Taufiquhadi prioritize the public interest and its interests as candidates for legislative members. This was conveyed by the Head of the Restu Team who stated this

The political message conveyed by the Restu NasDem Team by paying attention to the educational, social and economic background of the Bogor community is related to the value system and tradition or culture, embedded in the spirit and hope that will be realized if elected as a legislative member. The message content is a political product delivered by Taufiqulhadi as a political communicator or legislative candidate for the DPR, first conveying the vision and mission of becoming a legislative member based on the NasDem party platform. Second, the notes that have been done by Taufiqulhadi in the past, and personal characteristics.

If we look at the content of the message conveyed by Taufiqulhadi it contains something which means that the public knows and understands how the role of DPR members prioritizes the interests of the people of Bogor Regency by using communication techniques or the message delivered is informative and educative. and persuasive so that they feel drawn and interested in choosing them to be reelected as legislative candidates. Furthermore, the message delivered is redundant or repetition by influencing the audience by repeating the message to the audience 
so that the audience pays attention to the message being conveyed. This is consistent with the results of research conducted by S. Arulchelvan, Anna S. Arulchelvan, Anna (2014) which states that Based on the vision and mission as explained above, then in the process of political communication, Taufiqulhadi conveyed the following message:

The message of the campaign is the ideas that the party/candidate wants to share with the voters. The message often consists of several talking points about policy issues. The points summarize the main ideas of the campaign and are repeated frequently in order to create a lasting impression on the voters. The message of the campaign is the ideas that the party/candidate wants to share with the voters. The message often consists of several talking points about policy issues. The points summarize the main ideas of the campaign and are repeated frequently in order to create a lasting impression on the voters

In addition, the tagline conveyed by Taufiqulhadi is based on "being ready for the Aspect of Wargi" Regency of Bogor from Wargi who is ready to convey the Aspirations of the Brothers of Bogor Regency. It prioritizes the interests of the aspirations of the people of Bogor Regency.

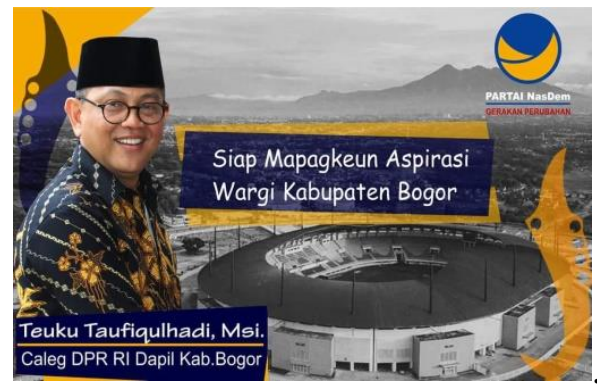

Figure 1: Taufiqulhadi Campaign Tagline

\section{Personal Note}

T. Taufiqulhadi in the past that he was educated in the Primary School in Sigli while the Junior High School in Banda Aceh. After graduating from high school, he entered the University of Jember, in 1982. On this campus he studied at the Department of International Relations, Faculty of Social and Political Sciences, until graduating in 1986. Then continued his education in the Political Postgraduate Program at the University Indonesia in 2007 and graduated in 2009. Currently, Taufiqulhadi is attending a doctoral program in Political Science at FISIP Padjadjaran University, Bandung. Taufiqulhadi's work as an Islamic activist began with students joining the Nahdlatul Ulama Student Association and then joining the Jember Branch of the Islamic Student Association in 1982. It was at this HMI that Taufiqulhadi was trusted to become the Chairperson. from the Nahdlatul Ulama Student Association and later joined HMI at the Jember Branch in 1982. and was elected as Chair of the Jember Branch HMI in 1986 at the 10th Conference. His last career at HMI was the HMI Executive Board for the period 1989 - 2000.

In the field of Da'wah, Taufiqulhadi is known as the first and only member of the Indonesian Parliament and the only initiator of the Digital Qur'an in Indonesia. This Android based 
application is the only digital newspaper that is equipped with Sundanese translations. In addition to Sundanese, the digital idea of Taufiqulhadi Newspaper is also equipped with translations of 11 regional languages, 9 international languages, prayer times and mosque locations based on Satellite / GPS and Sahih Hadith Features. This digital media has been officially launched by Indonesian Vice President Jusuf Kalla and Chair of the Indonesian Ulema Council on 2 Ramadhan 2017 yesterday. The launching ceremony was also attended by the Chairperson of the Indonesian Parliament, Chair of the Indonesian People's Consultative Assembly, Nahdlatul Ulama leaders, Muhammadiyah leaders, ranks of ministers and ambassadors of friendly countries whose language is used in digital newspapers. Taufiqulhadi initiated this digital Koran as his responsibility in the field of Islamic da'wah especially the propaganda of the Qur'an

\section{Personal Characteristics}

Taufiqulhadi is a humble person, loves his family and really appreciates the opinions or input given to him

What is explained above is in accordance with what was stated by Niffenegger (in Tosepu, 2017) dividing political products into three categories, (1) party platforms, (2) past records (records of things done in the past), and (3) personal characteristics. The main product of political institutions is a platform, which contains the concepts, ideas, ideological identity of parties, and party work programs. In addition, the strategy to package the political message conveyed by Taufiqulhadi played an important role in directing the way the Bogor Regency people interpreted it. The message raised is considered in accordance with political problems or problems that develop in society. The political message was delivered openly and revealed that the problem was being faced by the community that needed to be dealt with immediately. An example of this case, as stated by Fahmi, is that

there is one member of the community who is trapped by legal issues, considering that Mr. Taufiqulhadi helped him by providing assistance and providing experts in the legal field so that the problem was resolved.

Furthermore, the message is not only in the form of discourse, but also contains a solution, a political message conveyed by Taufiqulhadi answering the needs of the community to get public attention. The main purpose of political campaign messages for candidates is to mobilize the community, so that political messages and packaging are easily understood in accordance with the targeted segment of society.

\section{Media Selection Strategy}

Media selection is an important factor in the penetration of political messages to the public. Knowing the different levels of media penetration (internet, $\mathrm{TV}$, radio, print media such as newspapers and magazines in an area is important to ensure the effectiveness of the political message that will be delivered in the implementation of legislative candidates in Bogor Regency). . 
From observations and interviews conducted with one of Restu's team members, Mulyono, information was obtained that:

The mass media used by Taufiqulhadi include: electronic media, namely print media such as posters, letters, leaflets, and website banners on the internet. by using media blogs, websites, mailing lists, and social networking sites, such as Facebook and Twitter. In a number of these media, it is possible to have a dialogical relationship through discussion forums, or comment on each other, because of their accessible nature to those who are also mobilizing a large number of people to attend "TablighAkbar" conducted during the month of Ramadan by giving lectures such as greed in the picture below this.

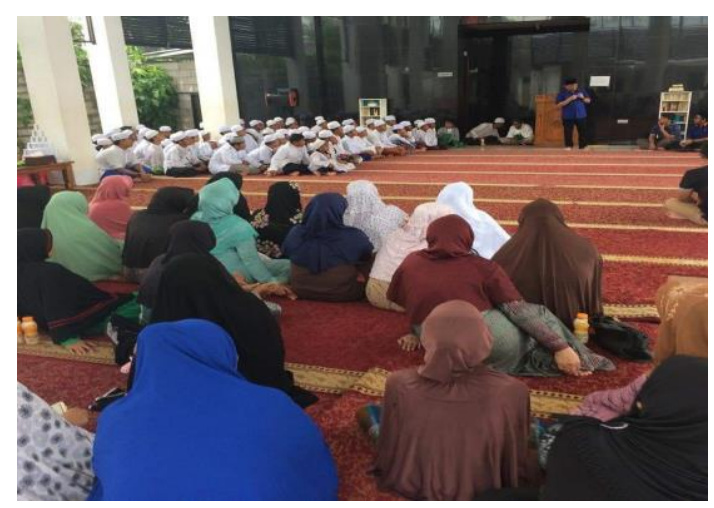

Figure 2: Tabligh Akbar Maulid Nabi

In addition to using the media, Taufiqulhadi uses interpersonal channels to the people of Bogor Regency who directly or face to face communicate by visiting religious and community leaders so that they know directly the aspirations of the people of Bogor Regency. The strategy to choose a media campaign is based on considerations that are in line with the current development of the media. This is consistent with the results of research conducted by Smith and Marx, 1994 that the new media took a stronger role. The sense of technological power as an important agent of change has a prominent place in the culture of modernity (Andrea Rommele, 2003). new media takes a stronger role. The sense of technological power as an important agent of change has a prominent place in the culture of modernity.

The effect of the use of the media carried out by the Restu Team is in fact there are obstacles because many people in the Bogor Kabuaten area do not know the figure of Taufiqulhadi because he is considered a newcomer and only found out when he was campaigning candidates for the DPR RI legislative candidates, and they considered Taufiqulhadi to not have expertise in made a speech. although his education level is good and his personality is also good. this is seen from the aspect of communication, the communication strategy adopted by Taufiqulhadi is effective. But the research findings obtained information that $\mathrm{T}$ Taufiqulhadi won the most votes compared to other candidates from different parties, but the NasDem party vote was small. 


\section{CONCLUSION}

Based on the discussion of the results of the research, it can be concluded that the political communication strategy in the implementation of the legislative election campaign for the DPR RI candidates through the stages of the audience selection strategy based on education, traditional / cultural and economic levels. While the message selection strategy was prepared and planned in advance based on the NasDem party platform, personal notes and personal characteristics of Taufiqulhadi. The technique of delivering messages is done in an informative, educative, and persuasive way. The media selection strategy is carried out through television, print and internet media. In addition, an interpersonal approach is taken. Although the political communication strategy used by Taufiqulhadi took place effectively, but because of the small NasDem party's vote, T Taufiqulhadi was not elected as a member of the Republic of Indonesia DPR 2019-2023 period. Obstacles in the implementation of the legislative election campaign that $\mathrm{T}$ Taufiqulhadi lacks the soul of an orator and is less well known to the people of Bogor Regency. The findings in this study are communication and leadership styles. Suggestions in this research are expected to be academically able to contribute to the development of communication science, especially political communication and it is suggested to research who want to examine this problem, using different communication theories and research methods.

\section{BIODATA}

Rika Permata Sari, SH works as a staff member for the National Democratic Party (NasDem) 2019 and is currently continuing the Postgraduate Masters Program in Communication Studies, InterStudi College of Communication, Jakarta, Indonesia

Poppy Ruliana, Dr. Dra. M.Si works as a lecturer at LLDIKTI Region III DKI Jakarta, Indonesia who is employed in the Master of Communication Studies Postgraduate Program to date.

Irwansyah, Dr., MA is a lecturer in the Department of Communication Science, FISIP University of Indonesia, Jakarta, Indonesia 


\section{REFERENCES}

\section{Books}

Arifin, Anwar. 2006. Imaging in politics. Jakarta: Indonesian library 2006, Political Communication (Paradigm - Theory - Application Strategy and Communication of Indonesian Politics), Jakarta: PT. Library Center

Bungin, Burhan. 2011. Qualitative Research. Jakarta: Kencana Predana Media Group

Cangara, Hafied. Political Communication: Concepts, Theories and Strategies. Jakarta: Rajawali Press, 2014

Creswell, Jhon W. 2016. Research Design Qualitative, Quantitative, and Mixed Approaches. Yogyakarta: Student Library.

Firmanzah. 2008. Political Marketing - Between Understanding and Reality . Jakarta: Indonesian Torch Foundation.

Kim Y. Robert, 2011. Case Study; Design and Method. PT. RajaGrafindo Persada. Jakarta

Mc Nair, Brian, 1999. An Introduction to Political Communication (2nd Edition). London: Routledge.

Pace \& Faules 2006. Organizational Communication in improving Performance, translated by Deddy Mulyana, BandungL Teen Rosdakarya

Sugiyono, 2009 ,. Understanding Qualitative Research, Bandung: Alfabeta

Swanson, D. \& Nimmo D. "New Directions in Political Communication: A Resource Book." Thousand Oaks: Sage, 1990,

Tosepu Ahmad Yusrin 2017, New Media in Political Communication (Political Communication in the Virtual World), Jakarta

Venus, Antar. Campaign Management: A Theoretical and Practical Guide to Effective Communication Campaigns. Bandung: Simbiosa Rekatama Media, 2009.

\section{Journal:}

Andrea Rommele, 2003. Political Parties, Party Communication and New Information and Communication Technologies. Sage Journal

Audrey A. Haynes, Julianne F. Flowers and Paul-Henri Gurian, 2002. Getting the Message Out: Candidate Communication Strategy during the Invisible

Primary. Political Research Quarterly Vol. 55, No. 3 (Sep., 2002), pp. 633-652

Saputra, Debie Pratama 2015 Political Communication Strategies of Legislative Candidates from the National Awakening Party (PKB) Towards 2014 elections in Kubar Regency, eJournal of Communication Studies 170-184I SSN

Surbakti, Ramlan 2006., Local Election, Direct Local Election and Future Otoda, in the Journal of Political Science, AIPI,

S. Arulchelvan, Anna 2014. New Media Communication Strategies for Election Campaigns: Experiences of Indian Political Parties. Online Journal of 
Communication and Media Technologies Volume: 4 - Issue: 3 - July 2014 University, India

\section{Electronic/Internet Source}

Jesper Strömbäck and Spiro Kiousis, 2014 . Strategic Political Communication In Election Campaigns,

https://www.researchgate.net/publication/263353301_Strategic_Political_Commu nication_in_Election_Campaigns

https://id.wikipedia.org/wiki/Teuku_Taufiqulhadi

https://www.partainasdem.id/

https://journals.sagepub.com/doi/abs/10.1177/135406880391002? journalCode=pp qa 